\title{
Iran: Den nye præsidents mange udfordringer
}

Jahangir Amuzegar

Hassan Rowhani står over for adskillige, voksende og forbundne udfordringer som øget international isolation og en nedsmeltende økonomi. Men sammenlignet med forgængeren vil han givet skinne og har et par personlige fordele

Lørdag d. 15. juni 2013 kunne Irans indenrigsminister, Hojat-al-Islam-valMoslemeen, meddele, at Hassan Rowhani, shiitisk præst på mellemniveau, var valgt til den Islamiske Republiks syvende præsident med 50,7 pct. af stemmerne (18 ud af 35 mio. stemmer). Rowhanis nærmeste rival fik kun 6,6 .

Rowhanis jordskredssejr var virkelig overraskende, da ingen af de sædvanlige politisk kloge i og uden for Iran havde forudset det resultatet (en ret god kender af iransk politik havde ikke givet ham chance for mere end 10 pct.).

Hans sejr skyldtes sikkert en pludselig og spektakulær opblomstring i valgkampens sidste dage, hvor to tidligere præsidenter og to storayatollaher, alle yderst kritiske over for den eksisterende politiske ledelse, gik stærkt ind til støtte for Rowhani.

Den endelige afstemning blev således en afvisning af de sidste otte års iranske indenrigs- og udenrigspolitik og i realiteten en virtuel folkeafstemning om den periode.

Rowhani var en blandt kun otte kandidater ud af 686, som Vogternes Råd tillod at stille op. De registrerede omfattede aktive politikere, tidligere ministre og medlemmer af parlamentet (Majlis), forretningsfolk, universitetsprofessorer, husmødre og en skøn samling mærkværdige typer. Det mærkeligste træk ved valget var imidlertid ikke den bizarre skare af aspiranter, men at Vogternes Råd også afviste, at tidligere præsident Hashemi Rafsanjani havde de "rette kvalifikationer". Rafsanjani er nuværende medlem af Eksperternes Forsamling og for- 
mand for Hensigtsmæssighedens Råd, landets øverste tribunal, der har ansvar for 'den bedste sikring af regimets interesser'.

\section{Den moderate stemme}

Den nye præsident opfattes hjemme og ude som en stemme for moderation og fornuft og en mand, som måske kan introducere en meningsfuld ændring af indenrigspolitikken og relationerne udadtil.

I virkelighedens verden kan disse forventninger imidlertid være overdrevne: Som et anerkendt medlem af Eksperternes Forsamling, Hensigtsmæssighedens Råd, Det Nationale Sikkerhedsråd og som tidligere medlem af parlamentet, Majlis, og tidligere atomchefforhandler er Rowhani en fuldblods insider. Han er hverken ikonoklast eller radikal reformmand og ikke engang sand liberal. Han tror alvorligt på streng shiitisk teologi og begrebet velayat-efaghih (teologisk styre), og han støtter fuldt ud Irans udemokratiske forfatning.

En stemme for ham måtte således anses for at være en stemme imod hans 'principalistiske' rivaler, en afvisning af den afgående administrations katastrofale politiske eventyrkurs udadtil og misrøgt af den hjemlige økonomi.

Ud fra alle indikationer og analyser efter valget var den afgørende stemme mere end noget andet en stemme for 'forandring'.
Om den valgte præsident vil blive den 'ideelle' chef, som beskrevet af den Øverste Leder, kan kun tiden fortælle. Efter ayatollah Khameneis opfattelse skal den ideelle præsident være vagtsom, modig og urokkelig i udlandsrelationer. I indenrigspolitik skal han have et konkret program, vise klogskab og en stærk tro på det, som statsoverhovedet har kaldt "den resistente økonomi”.

\section{Valgtemaer}

Af de tre tv-transmitterede debatter mellem præsidentkandidaterne om økonomiske problemer, samfundskulturelle emner og udenrigsrelationer - var det den om landets økonomiske problemer, som blev set og diskuteret af flest iranere. Emnerne, som var valgt af tv-producenterne, omfattede: planer for økonomisk retfærdighed; foranstaltninger imod de faldende indtægter fra olieeksport; styrkelse af hjemmeproduktionen og beskyttelse af arbejdsmarked og kapital; anden fase af Målprogrammet for Subsidier; arbejdsløshed; boligpolitik og priskontrol og relationerne til andre hjemlige forfatningsmæssige magtcentre og overvågende organer.

Ingen af kandidaterne havde konkrete planer. Deres forslag gik fra vage løfter om 'at forbedre forretningsklimaet' til 'at øge indtægter fra ikke-olie eksport' og endelige til grandiose opråb om at 'slå kapitalismen, kommunismen og zionis- 
men på den globale scene og skabe et islamisk imperium'.

Rowhanis svar på de stillede spørgsmål omfattede: hjemmeproduktion frem for import, decentralisering og kamp imod korruption; at erstatte olieeksport med eksport af petrokemiske produkter; sand privatisering og forbedring af handels- og erhvervsklimaet; udbetaling af kontante subsidier kun til fattige og et program for billige boliger.

I sine erklæringer efter valget har Rowhani signaleret, at hans dagsorden vil blive domineret af bestræbelser for at genoplive Irans stagnerende økonomi, styrke den devaluerede nationale valuta, kontrollere likviditeten, forøge de hjemlige investeringer og forbedre målrettede subsidier.

\section{Mange handicaps}

Alt tyder på, at den nye præsident står over for udfordringer, som overgår dem, som hans seks forgængere mødte (den eneste undtagelse var givet den første præsident, Abolhasan Bani Sadr, der måtte klare sig igennem med en massiv hjemlig politisk opposition og invasionen fra Irak).

I betragtning af karakteren af Rowhanis udfordringer er det umuligt at sige, om han får heldet med sig. Hans handicaps er mange og forskellige. For det første havde han kun støtte fra lidt mere end halvdelen af vælgerne - mindre end nogen tidligere præsident. For det andet mangler han en egen politisk organisation: hans støtter omfatter nu en uformel og improviseret koalition af lunkne reformfolk, entusiaster i centrum og selv nogle skuffede, men marginale konservative. Som tiden går og problemer forbliver uløste, vil denne skrøbelige 'alliance' formentlig begynde at falde fra hinanden.

Endelig må han finde en opus operandi med andre for de flestes vedkommende konservative nationale institutioner, retssystemet, Vogternes Råd, TV og Radioorganisationen, den magtfulde og økonomisk dominerende Revolutionsgarde, Basij militsen, høgene i klerikale cirkler og den højreorienterede skrevne presse, ledet af avisen Kayhan.

\section{Vejen til normalitet}

Ufordringerne for den nye præsident er delvist eksterne, men i hovedsagen baseret hjemme. De ydre udfordringer, som overskygger alle Irans andre problemer, er at afmontere spændingerne med Vesten over atomprogrammet, nå til en détente med andre regionale magter, styrke samarbejdet med det Internationale Atomenergiagentur og forbedre Irans slemt besmittede image i det internationale samfund. Med andre ord nødvendige foranstaltninger for at mildne de forkrøblende vestlige sanktioner og styre iransk økonomi tilbage til normalitet. 
Denne opgaves presserende karakter afspejler den bratte erkendelse hos topembedsmænd, at deres tidligere bragesnak om de gavnlige effekter af økonomiske sanktioner, som ansporer til større selvforsyning, alt sammen er forsvundet ud i mørket.

Faktum er, at de nuværende foranstaltninger, især de alt omfattende restriktioner, der trådte i kraft 1 . juli 2013, hærger den iranske økonomi. Og trods gentagne forsikringer fra dem, som har indført sanktionerne, at de ikke tager sigte på at ramme det iranske folk men på at ændre regimets opførsel, har det omvendte været sandt.

Folk lider ubærligt, mens regimet stædigt forfølger det, som det hævder er dets juridiske ret.

Af disse grunde er den første prioritet for den nye præsident at gøre en ende på konfrontationen med Vesten og nå en gensidig tilfredsstillende ordning med $5+1$ gruppen (de fem permanente medlemmer af FN's sikkerhedsråd USA, Rusland, Kina, Frankrig og Storbritannien plus Tyskland). At få fjernet sanktionerne er altafgørende for den iranske økonomi.

\section{Hjemlig dagsorden}

Den nye præsidents hjemlige prioritet er at redde den 'syge økonomi', der lider af langtrukket recession, galopperende inflation og betragtelig arbejdsløshed. Ifølge en rapport i april 2013 fra Den Internationale Valutafond faldt Irans BNP med 1,9 pct. i 2012 og ventes at falde med 1,3 pct. i år. (Irans nuværende økonomiske femårsplan er baseret på en årlig vækst på 8 pct.).

Inflationen er et andet enormt problem. I en rapport i juni 2013 fra Verdensbanken, der er bekræftet af Irans egen Nationalbank og Statistiske Bureau, sættes den årlige inflation til 40 pct. og er således blandt verdens højeste og den højeste i Iran i 17 år. Fødevarepriserne er følge Irans Statistiske Center steget med over 60 pct. Receptpligtig medicin er steget med 40 til 90 pct. Jordpriserne i hovedstaden steg med mere en 150 pct. sidste år. Private iagttagere sætter rutinemæssigt spørgsmålstegn ved den iranske regerings inflationstal og anser den reelle inflation for at være meget højere.

Arbejdsløsheden er en tredje større knibe. Det Statistiske Bureau sætter den nuværende arbejdsløshed til 12,2 pct. plus 8,9 pct. underbeskæftigede og arbejdsløsheden for de 15 til 24-årige til 26,9 pct. Nøjagtige og samstemmende tal for Irans arbejdsmarked er en sjældenhed. Ifølge en rapport fra arbejdsministeriet er 5,5 millioner mennesker i de seneste syv år kommet ind på arbejdsmarkedet, og omkring 5,2 millioner nye jobmuligheder er skabt, så den totale arbejdsløshed kun skulle være steget med 300.000 til tre millioner.

Et medlem af majlis' arbejdskom- 
mission afviser de officielle tal og skønner, at arbejdsløsheden på nationalt plan er så høj som 30 pct. Efter hans opfattelse er den officielle arbejdsløshed så lav som tre millioner, fordi den bl.a. ikke indregner 'kvinder og universitetsstuderende'.

Iranske analytikere skønner, at trods regeringens påstand om at have skabt tre millioner nye job, er det i realiteten ikke over 100.000, som det rent faktisk er blevet til. Og grunden til at den officielle arbejdsløshed er uændret på omkring tre millioner er, at de 16 millioner babyer, som i 1980'erne stod parate til det mistrøstige arbejdsmarked, i de sidste fem år har besluttet at drage nytte af den gratis mulighed at tage en højere uddannelse på statslige universiteter. Som et resultat heraf udgør den nationale arbejdsstyrke kun 34,7 pct. af landets befolkning en af de laveste andele i verden set i forhold til sammenlignelige lande. Tre millioner universitetsuddannede kommer nu ind på arbejdsmarkedet og søger job, der svarer til deres nyerhvervede kvalifikationer.

Løsningen på disse tredobbelte problemer kan bedst anskues ud fra det umiddelbare (første år), det kortsigtede (andet år) og det mellemlange sigt (fire år) .

\section{Øjeblikkelige opgaver}

Rowhanis umiddelbare $ø$ konomiske opgave bliver at takle dette års budgetunderskud, som er en vigtig grund til Irans systemiboende inflation. Det nuværende budget er baseret på eksport af 1,3 mia. tønder olie til 95 dollar per tønde, hvilket forekommer temmelig optimistisk, især da olieeksporten faldt til 700.000 tønder i juni, det laveste i 25 år. Budgetunderskuddet forventes at blive omkring 30 milliarder dollar på grund af det allerede betragtelige fald i olieeksporten, den begrænsede hjemlige skattebetaling på grund af recessionen og betragtelige finansielle forpligtelser, indgået af Ahmadinejad-administrationen.

I betragtningen af centralregeringens rapporterede enorme (men endnu udeklarerede) gæld til banksystemet, statslige virksomheder og private ville den kloge måde at have at gøre med underskuddet være at udstede kortfristede værdipapirer til offentligheden til lav rente, bruge indtægter ved valutaomveksling, som er resultat af regeringens kunstigt høje rente, sælge tabsgivende statslige virksomheder og midlertidigt udsætte ikke-påtrængende udviklingsprojekter.

Den anden øjeblikkelige foranstaltning burde være at gøre en ende på den mangesidede valutavekslingsrate og etablere en enhedskurs baseret på en rational formel for købekraften mellem iranske rial og amerikanske dollar. En flydende enhedskurs skal gælde alle former for handelsefterspørgsel, uanset deres karakter eller vigtighed. Den 'vitale' efterspørgsel på udenlandsk valuta 
(til import af bl.a. mad og medicin) bør kompenseres af særlige subsidier snarere end af forskellige vekselkurser. Der bør samtidig gøres en ende på det frie (sorte) marked.

Den tredje øjeblikkelige prioritet bør være at tage fat om inflationen med streng kontrol med likviditeten og begrænsning af kommercielle bankers lån fra Centralbanken. Den fjerde hastende prioritet er at skabe orden i det nuværende Målprogram for Subsidier, som er et nytteløst dræn i finansministeriets sparsomme ressourcer.

Det nuværende system består i at sælge statsligt producerede energiprodukter til højere priser og fordele afkastet i månedlige udbetalinger til næsten hele befolkningen. Det har vist sig at være tabsgivende, inflationsskabende og skadeligt for de energiintensive små private industrier.

Programmets basale filosofi, modus operandi, finansiering og begunstigelser må revideres gennemgribende og gentænkes. En fast og bindende koordinering af skatte-, penge- og vekselpolitikker er essentiel for realisering af disse opgaver.

\section{På kort sigt}

Den nye præsidents kortsigtede opgaver vil være 1) gøre noget ved skatternes mindre rolle i BNP og det skattemæssige budget og 2) øge arbejdsproduktiviteten.

Den Islamiske Republik er for- mentlig et af verdens mindst beskattede og mest subsidierede lande. Omkring 40 pct. af det samlede nationalprodukt er legalt fritaget for skat og yderligere 20 pct. består af smugling i undergrundsøkonomien. De skatter, som bliver betalt af de resterende 40 pct. er langt under det eksisterende behov.

På trods af et på papiret moderne og progressivt skattesystem (inklusive moms) udgår skatter mindre en 7 pct. af BNP og kun 25 pct. af det årlige skattebudget på grund af fejlslagne strukturer og bedrøvelig skatteinddragelse.

Af de omkring 400.000 registrerede forretningsvirksomheder er det kun 193.000, der gør sig den ulejlighed at udfylde selvangivelser. Mens små private virksomheder (asnaf) producerer omkring 30 pct. af det samlede nationalprodukt, er deres andel af skatterne mindre end 5 pct. 75 pct. af statsbudgettet består af indtægter fra olieeksport, salg af statsvirksomheder og lån fra Nationalbanken.

Arbejdsproduktiviteten er desuden frygtelig lav. Ifølge forskellige private estimater, der underbygges af lejlighedsvis officielle data, er det ugentlige 'nyttige' arbejde anslået til 11 timer per arbejder, sammenlignet med 60 timer i Japan og 74 timer i Sydkorea.

Det årlige 'frugtbare' arbejde i Iran er gennemsnitligt 800 timer sammenlignet med 2.420 i Japan, 1.330 i Tyrkiet og 1.100 i Pakistan. 
På grund af et stort antal officielle helligdage (inkluderet weekends) er det totale årlige antal arbejdsdage på kun 156 i Iran.

Den tredje helt centrale opgave på mellemlangt sigt for den nye præsident vil være at give Den Islamiske Republiks basale økonomiske struktur et grundigt eftersyn. Den er en arv fra det radikale venstre i den oprindelige forfatning og dens endnu mere problematiske tilføjelser.

\section{Mellemlangt sigt}

Denne opgave minder om det, som tidligere præsident Ahmadinejad kaldte "Den store økonomiske operation" (24. nov. 2008). Det bør omfatte:

1) Nedskæring af den meget store og meget ineffektive offentlige sektor (der er karakteriseret af et stigende antal veje ind for Revolutionsgarden).

2) Rette op på et ufavorabelt klima for handel og business, der er skabt af mafia-lignende private monopoler og andre forhindringer for at komme ind.

3) Fjernelse af den belastende og urentable regulering af banksystemet.

4) Hurtigere og mere gennemskuelige privatiseringer af statslige tabsgivende virksomheder.

5) Afslutning på løn- og priskontrol.

6) Etablering af en permanent og politisk sikret oliestabiliseringsfond. 7) Ophævelse af den fødselsfrem- mende politik, som blev indført for nylig efter det sidste årtis succesrige foranstaltninger til folkekontrol.

Hvis man ser bort fra uforudsete betingelser, skulle Hassan Rowhani have en ret god chance for succes. Da han er en 'diplomatisk sheikh', modig og med et åbent sind - med prisværdige forhandlingserfaringer og -evner - er han overordentlig kvalificeret til opgaven at nå et gensidigt acceptabelt kompromis med Vesten.

\section{Rowhanis fælde}

Men fælden er, at ifølge den iranske forfatning er alle områder af vital national interesse styret og bestemt af den Øverste Leder og gennemført af Det Nationale Sikkerhedsråd, som præsidenten dog leder. Irans nuværende holdning til atomprogrammet, som er dikteret af ayatollah Khamenei, er en af de sager. Håbet er, at Rowhani som den Øverste Leders mangeårige betroede repræsentant i Det Nationale Sikkerhedsråd kan overtale denne til at handle.

På den hjemlige front er hans kvalifikationer også bedre end de flestes. At dømme efter hans erklæringer ved adskillige lejligheder virker han vidende om økonomiske forhold. Hans bestseller bog med titlen National Sikkerhed og Irans Økonomiske Regime, som er udgivet af Hensigtsmæssighedens Råds Strategiske Studiecenter, vidner om hans bevidsthed om basale problemer og de mu- 


\section{BAGGRUND}

lige løsninger på dem. Under et nyligt besøg i (den hellige by) Qom for at tale med forskellige gejstlige, udtrykte Rowhani bekymring for de problemer, som Irans industri og landbrug står overfor.

Og mere betydningsfuldt var et møde med ledelsen af Irans Kammer for Handel og Industri 7. juli, hvor han sagde, at han ikke tror på 'kommandoøkonomi' (dastouri) og mener, at regeringens pligt er at fastlægge politikken og sørge for dens iværksættelse snarere end at engagere sig direkte i landets økonomiske aktiviteter.

Men frem for alt vil Hassan Row- hani givet skinne klart i sammenligning med og på baggrund af den hårde kritik af den afgåede administration fra alle præsidentkandidaterne.

Dr. Jahangir Amuzegar er international фkonomisk rådgiver, tidligere medlem af IMF's ledelse. Han var Irans handelsminister (1962-63), finansminister (1963) og ambassadør uden portefølge (196379). Hans mange udgivelser omfatter 'Managing the Oil Wealth: OPEC's Windfalls and Pitfall' (I.B. Tauris, 1999).

Oversat fra engelsk af Vibeke Sperling. 